\title{
Finished Product Warehouse Layout Design Using Shared Storage Method
}

\author{
Juliani Febiyanti \\ Department Of Electrical Engineering, University Of North Sumatra, Jl. Dr. Mansur No. 9 Padang Bulan, Kec. \\ Medan Baru, Kota Medan 20222
}

\begin{tabular}{|c|c|}
\hline ARTICLE INFO & ABSTRACT \\
\hline Article history: & $\mathrm{PT} . \mathrm{XYZ}$ is a private company engaged in the business of producing \\
\hline $\begin{array}{r}\text { Received Feb 05, } 2020 \\
\text { Revised Mar 12, } 2020 \\
\text { Accepted Apr 30, } 2020\end{array}$ & $\begin{array}{l}\text { ceramics. The problem in the current warehouse is the presence of } \\
\text { defective ceramic products due to irregular placement of finished } \\
\text { products. Irregular placement of ceramic products, which can cause } \\
\text { inefficiency in picking time and make it difficult for workers because }\end{array}$ \\
\hline $\begin{array}{r}\text { Keywords: } \\
\text { Facility Layout } \\
\text { Warehouse Design } \\
\text { Shared Storage Method }\end{array}$ & $\begin{array}{l}\text { workers on the production floor. The above problems can be } \\
\text { overcome by using the Shared storage method where goods are } \\
\text { placed in the storage area closest to the entrance-exit (I/O) door. } \\
\text { This method would be better used in types of factories that have the } \\
\text { same product dimensions or not much different. The lack of good } \\
\text { procedures for arranging goods in the warehouse causes problems } \\
\text { in the warehouse, so that the warehouse seems cramped and less } \\
\text { organized. The condition of the warehouse layout that is not based } \\
\text { on a comprehensive layout design can lead to inefficiency in the time } \\
\text { of taking and storing materials and making it difficult for operators to } \\
\text { handle materials due to warehouse limitations. In this case, the } \\
\text { process of placing goods in the warehouse at the ceramic factory of } \\
\text { PT. XYZ will be arranged to reduce the forklift movement distance } \\
\text { shorter which can be seen from the results of the proposed design } \\
\text { on the layout of the finished product placement in the warehouse. } \\
\text { Looking at the design of the proposed ceramic product warehouse } \\
\text { layout, the percentage of total travel distance savings in the finished } \\
\text { product warehouse is } 37.76 \% \text {. }\end{array}$ \\
\hline
\end{tabular}

This is an open access article under the CC BY-NC license.

\section{Corresponding Author:}

Juliani Febiyanti,

Department Of Electrical Engineering,

University Of North Sumatra,

Jl. Dr. Mansur No. 9 Padang Bulan, Kec. Medan Baru, Kota Medan 2022.

Email : julianifebiyanti@gmail.com

\section{INTRODUCTION}

In this era of globalization, more and more industries are competing with each other. This makes all entrepreneurs engaged in the industry have to further improve the competitiveness of their companies. To increase competitiveness, it is necessary to improve the problems that occur in the company.

PT. $X Y Z$ is a manufacturing company that produces ceramics. The company does make-toorder production. PT. XYZ has one warehouse for finished ceramic products with an area of $64 \mathrm{mx}$ 
$32 \mathrm{~m}$. Based on observations at the finished product warehouse at PT. XYZ which is engaged in the production of ceramics. The problems that exist in the current warehouse are defective ceramic products due to irregular placement of finished products, inappropriate placement of ceramic products where the goods with the highest frequency of delivery and which often go in and out are closer to the exit, distance of travel (distance). travel) far away. According to the Swift Journal (2016), the settings in the layout determine the amount to be stored as semi-finished materials or raw materials that are ready to process, In determining the steps for the layout of a warehouse, several steps are needed, namely: calculating the area capacity, calculating the area requirements for each material, determining the layout and moving for each area. The process of product placement in the shared storage method is to arrange storage areas based on the condition of the warehouse floor area, then sort the area closest to the area farthest from the $1 / 0$ entrance, so that the placement of goods that will be sent immediately is placed in the area that is most close and so on. Shared storage is a method of arranging the layout of the warehouse space using the FIFO (First In First Out) principle where goods that are quickly sent are placed in the storage area closest to the entrance-exit ( $\mathrm{I} / \mathrm{O})$ door. This method would be better used in the type of factory that has the same product dimensions or not much different. Because each storage area can be occupied by different types of products based on the production time and delivery date of the product.

The problem with the finished product warehouse is the irregular placement of stacks so that the warehouse looks narrow, the distance between the stacks is too close to the width of the aisle (alley). This makes it difficult for forklifts to pick up ceramic products and products that are in the forklift area are damaged by being hit by a forklift. Placement of products that have the highest frequency of delivery and which often go in and out far from the entrance/exit, as well as long distance travel.

In the picture, the current state of the warehouse explains that the location of ceramic products is very far from the entrance / exit. So that the forklift requires a long journey to reach it.

The reason for using the shared storage method is because the problems faced by ceramic factories occur in the finished product warehouse. Poor placement of goods in the warehouse causes problems in the warehouse so that the warehouse seems cramped, the distance between the stacks is too close to the width of the aisle (alley), the products in the forklift area are damaged due to being hit by a forklift. Distance travel that is far from the entrance/exit when picking up/placing ceramic products. Even though a company has succeeded in achieving success, basically there is always a better way to achieve success, it may be faster, cheaper, simpler or safer.

\section{RESEARCH METHOD}

\subsection{Types of research}

The type of research used in this research is case study 9 , a type of research on the status of the research subject with respect to a specific phase of the whole personality (Maxfield, 1930). With this research, the researcher wants to study intensively the background and interactions of the object of research with the aim of providing a detailed description of the background, characteristics or characteristics that are tried to be generalized.

\subsection{Conceptual Framework}

The conceptual framework shows the logical relationship between the variables that have been identified that are important and become the foundation for carrying out research. 


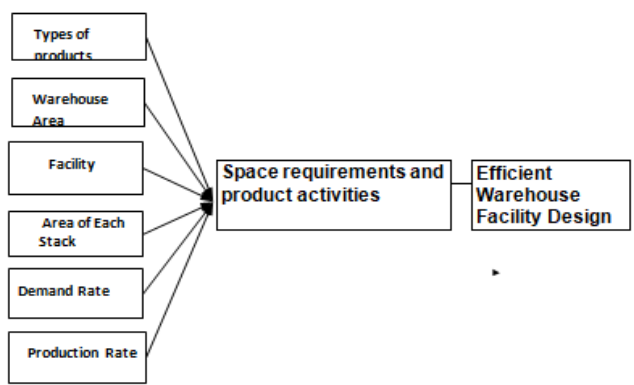

Figure 1. Conceptual framework

\subsection{Research variable}

The variables that will be observed in this study are the independent variable (independent variable) and the dependent variable (the dependent variable). The dependent variable is a variable that is the main concern in the study. While the independent variable is a variable that affects the dependent variable, either positively or negatively (Sekaran, 2006).

\section{RESULTS AND DISCUSSIONS}

\subsection{Ceramic Product Placement Results}

The process of placing ceramic products in the shared storage method is to arrange storage areas based on the condition of the warehouse floor area, then sort the area closest to the area farthest from the $1 / O$ entrance, so that the goods to be sent are placed in the closest area. and so on. Shared is a method of managing the layout of the warehouse space using the FIFO (First In First Out) principle where goods that are quickly sent are placed in the storage area closest to the I/O entrance and exit. Alternative design on layout based on forklift diagonal.

\section{a. Space Requirements}

The average number of requests for all $20 \times 25$ ceramic products in one month is 19442 boxes, while $30 \times 40$ ceramics is 10669 boxes. With the storage capacity of products in one stack is 4 pallet levels.

After three alternative designs, namely alternative I, alternative II and alternative III were carried out to obtain a more accurate design. In data collection and data processing using the shared storage method in the finished product warehouse, PT. XYZ, it can be concluded that alternative layouts have a smaller total mileage. The design chosen is alternative design I because it saves more total travel time than the initial layout by improving the arrangement of storage products. The total mileage of the initial layout is $38603.84 \mathrm{~m} / \mathrm{month}$. The total mileage for alternative layout I is $24023.3 \mathrm{~m} / \mathrm{month}$. There is a difference in the total mileage value of 14580.54 $\mathrm{m} /$ month from the total initial mileage. This means that alternative layouts can shorten the distance traveled by warehouse employees in picking up goods.

The placement of finished goods is not regular and does not yet have an aisle area that can reach all finished goods easily, and ceramics are also located far from the entrance/exit of the warehouse. The improvement design is carried out, by placing the product in a storage area (stack) which is arranged according to the aisle (alley) configuration. The use of the aisle configuration can reduce the time and distance of forklift travel during the loading and unloading process, because there is no need to rearrange the product after the loading and unloading process is carried out.

The comparison analysis of the accessible storage area expected in the initial conditions with alternative conditions is:

1) By setting alternative alternative $I$ in the ceramic product warehouse on the aisle which is regular it can run smoothly for forklift trips.

2) The total travel distance will be minimal. 
3) Setting the distance between the stacks due to product damage during the loading and unloading process on the forklift can be reduced to $0 \%$.

\subsection{Using the Shared Storage Method}

The use of the Shared Storage method aims to organize products in the warehouse with the number of products in accordance with customer requests with a closer distance. With the shared storage method, customer requests can be met efficiently and delivery on time. Because the product with the highest throughput value will be placed in the stack with the closest distance to the warehouse exit door, so that the product with any large demand, and in the shortest time according to production capacity will be fulfilled more efficiently and on time. This can be done because of the shared storage method.

The advantage of product placement using alternative $I$ is that the distance between the doors to the product storage is closer, the forklift can reach all products because an aisle is provided for the forklift, the total travel distance of alternative 1 is smaller than now. With the placement of ceramic products with alternative 1 above, the utilization of the storage area (stack) will be obtained, which is $14580.54 \mathrm{~m} / \mathrm{month}$ and savings in the distance of forklift travel during the loading and unloading process.

\section{CONCLUSION}

The conclusion that can be drawn after collecting and processing data using the Shared Storage method at the ceramic product warehouse of PT. XYZ is: Total floor area requirement is $508.2 \mathrm{~m} 2$. The percentage of total travel distance savings in the finished product warehouse is $37.76 \%$. The minimum travel distance obtained in this study was 24023.37 ( $\mathrm{m} / \mathrm{month})$.

\section{REFERENCES}

Ampuh, Rika Hadiguna, dkk. 2008. Tata Letak Pabrik. Andi: Yogyakarta Apple, James. 1990. Tata Letak Pabrik dan Pemindahan Bahan. Bandung: ITB

Ardiansyah, Firman. 2012. Perencanaan Tata Letak Gudang Menggunakan Metode Shared Storage di Pabrik Plastik Kota Semarang.

Francis, R. L. 1992. Facilities Layout and Location: An Analitycal Approach $\quad 2^{\text {nd }}$ Edition New Jersey: Prentice-Hall Inc.

Hadi, Indramawan. 2016. Tata Letak Gudang Raw Material Chemical Menggunakan Metode Shared Storage dan Rel Space. Sidoarjo: Teknik Industri Universitas Muhammadiyah

Mulcahy, David. 1994. Warehouse and Distribution Operation Handbook International Edition. New York: McGraw Hill.

Purnomo, Hari. 2004. Perencanaan dan Perancangan Fasilitas. Yogyakarta: Graha Ilmu.

Sinulingga, Sukaria: Metode Penelitian, Edisi Pertama, Graha Ilmu, Yogyakarta Wignjoesoebroto, Sritomo. 1996. Tata Letak dan Pemindahan Bahan. Surabaya: ITS 